\title{
PENGARUH KARAKTERISTIK SISTEM INFORMASI AKUNTANSI MANAJEMEN TERHADAP KINERJA MANAJERIAL PADA BPR DI KOTA BANDAR LAMPUNG
}

\author{
Anggun Novitasari1, Reni Oktavia ${ }^{2}$, Pigo Nauli3 \\ ${ }^{1}$ Fakultas Ekonomi dan Bisnis, Universitas Lampung \\ 2 Fakultas Ekonomi dan Bisnis, Universitas Lampung \\ 3 Fakultas Ekonomi dan Bisnis, Universitas Lampung
}

\section{Informasi Naskah}

Update Naskah:

Dikumpulkan: 3 April 2020

Diterima: 20 April 2020

Terbit/Dicetak: 17 Juli 2020

\section{Keywords:}

BPR, Managerial Performance, Broadscape,Timeliness, Aggregation, Integration

\section{Abstract}

$B P R$ face difficulties with the high ratio of non-performing loans and competition for peer-to-peer landing online or financial technology (fintech) which was published in CNBC Indonesia. To survive in the sphere of intense business competition, where in the future there will be many digital economic developments, the emergence of products that are increasingly integrated in various financial companies, business must be able to create flexible and innovative business conditions, and must also consider external factors of their business. It must also be followed by technological developments in order to survive and be able to compete in global competition. The high competitiveness created by a business actor can be achieved in one way, which is by increasing managerial performance. This study aims to analyze the influence of the characteristics of management accounting information systems on the managerial performance of rural banks. This study uses primary data using a survey method by giving questionnaires to operational managers of BPR in the city of Bandar Lampung. Based on the research results, it is known that broadscape, timeliness, aggregation, integration significantly and positively affect managerial performance 


\section{A. PENDAHULUAN}

Kondisi krisis BPR menghadapi kesulitan dengan tingginya rasio kredit yang bermasalah dan persaingan pinjaman online atau financial technology (fintech) peer to peer landing yang dilansir dalam CNBC Indonesia. Untuk tetap bertahan dalam lingkup persaingan bisnis yang begitu ketat, dimana kedepannya akan banyak perkembangan digital ekonomi, munculnya produk - produk yang makin terintegritas di berbgai perusahaan keuangan, pelaku bisnis harus dapat menciptakan kondisi bisnis yang fleksibel dan inovatif, dan juga harus mempertimbangkan faktor eksternal usahanya itu juga harus diikuti oleh perkembangan teknologi agar dapat bertahan dan mampu bersaing dalam persaingan global. Tingginya daya saing yang diciptakan oleh suatu pelaku bisnis dapat dicapai dengan salah satu cara yaitu meningkatkan kinerja manajerial.

Menurut Spencer et al (2012) dalam meningkatkan kinerja manajerial suatu perusahaan terdapat beberapa kemampuan manajer dalam melaksanakan kegiatan manajerialnya diantaranya perencanaan, koordinasi, pengawasan, investigasi, evaluasi, pengaturan staff, negosiasi dan perwakilan. Dalam meningkatkan kinerja, maka manajemen sautu perusahaan atau pelaku bisnis harus memiliki kemampuan untuk memanfaatkan peluang yang ada dan terlihat, mengidentifikasikan permasalahan, dan mengimplementasikan proses adaptasi perkembangan bisnis yang kian meningkat dengan cepat. Manajemen berkewajiban untuk mempertahankan kelangsungan hidup serta mengendalikan perusahaannya atau bisnisnya. Hal itu dapat dilakukan jika manajer paham akan sistem infromasi akuntansi manajemen sebuah perusahaan.

Sistem akuntansi manajemen harus tergambarkan dari perspektif pengambilan suatu keputusan yang strategis, karena itulah hanya informasi yang terlihat relevan untuk suatu pengambilan keputusan tertentu yang telah disediakan. Informasi tersebut yang telah dikumpulkan akan dilakukan analisis oleh akuntan manajemen. Oleh sebab itu, infromasi sangat dibutuhkan oleh seorang manajer untuk memberikan keputusan yang tepat dan akurat (Sigilipu, 2013).

Menurut Ghasemi et al (2016) sistem informasi akuntansi manajemen salah satu fungsinya untuk menyediakan informasi penting guna mengontrol manajer dalam melakukan pengendalian aktifitasnya. Informasi yang penting bagi suatu perusahaan untuk kegiatan perencanaan, pengambilan keputusan dan kontrol. Chenhall dan Morris (1989) dan Soobaroyen (2008) mengungkapkan ada beberapa karakteristik sistem infromasi akuntansi manajemen diantaranya Broad Scope (lingkungan), Timelines (ketepatan waktu), Aggregation (agregasi), dan Integration (integrasi).

Berdasarkan data Otoritas Jasa dan Keunagan peningkatan kinerja dalam pembiayaan kredit mikro UMKM BPR memiliki pangsa tertinggi yaitu 69,7\%. Regulasi BPR yang tidak seketat bank umum serta lokasi yang berdekatan dengan usaha mikro. BPR secara umum modalnya masih sama, relatif sekitar $22 \%$ dengan pertumbuhan yang agak melambat karena dipengaruhi oleh faktor global. Nominal kredit mikro BPR hanya sebesar $13,79 \%$. Penyaluran kredit mikro yang terbilang rendah ini antara lain karena infrastruktur dan permodalan yang rendah, sumber dana yang rendah, jaringan kantor yang tidak mencangkup secara keseluruhan, serta kuantitas dan kualitas SDM yang kurang memadai jika dibandingkan dengan Bank Umum. 


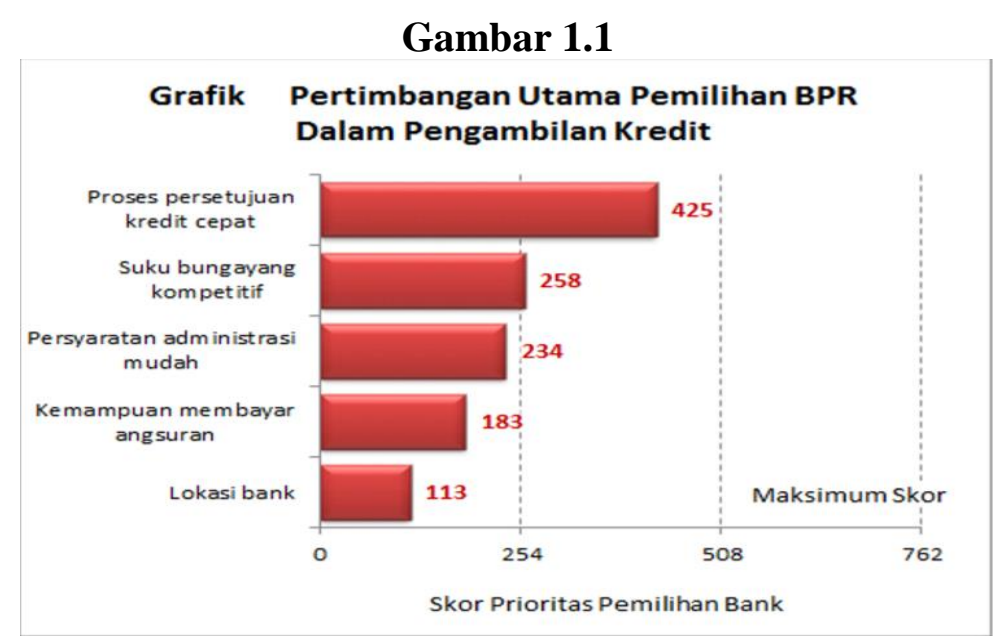

Sumber : Bank Indonesia (2013)

Melihat kinerja dalam perkembangan pembiayaan kredit mikro BPR di Indonesia, sistem infromasi akuntansi manajemen adalah salah satu faktor yang penting dalam sebuah manajamen perusahaan perbankan. Bank Pengkreditan Rakyat (BPR) yang beroperasi di daerah atau kecamatan. BPR sendiri melakukan kegiatan transaksi dengan menerima simpanan dari luar berupa uang dan menyalurakannya kembali untuk kalangan bawah dalam bentuk pinjaman (Budisantoso dan Nuritomo, 2016).

Menunjang perkembangan BPR saat ini membutuhkan sistem informasi akuntansi manajemen dengan baik supaya dapat berjalan dengan baik. BPR harus meningkatkan sistem informasi akuntansi manajemennya untuk mendapatkan informasi yang tepat dan terpercaya. Perkembangan teknologi yang semakin canggih BPR diharuskan melakukan inovasi dan perubahan yang lebih baik dalam menggunakan aplikasi sistem informasi akuntansinya sehingga laporan yang dihasilkan dapat memberikan hasil yang relevan bagi manajemen dalam mengambil keputusan dan juga untuk pihak eksternal yang memerlukan informasi laporan keuangan BPR. Dari latar belakang diatas, peneliti tertarik untuk menganalisis Pengaruh Karakteristik Sistem Informasi Akuntansi Manjaemen Terhadap Kinerja Manajerial BPR. Penelitian ini menggunakan data primer dengan menggunakan metode survey dengan memberikan kuisioner terhadap manajer operasional BPR di Kota Bandar Lampung.

\section{B. LANDASAN TEORI DAN PENGEMBANGAN HIPOTESIS}

\section{Teori Kontijensi}

Pusat hubungan contingency theory antara suatu organisasi dengan lingkungannya. Lawrence dan Lorsch (1967) secara jelas menunjukkan bahwa organisasi-organisasi yang sukses selalu disusun strukturnya dalam pola yang konsisten dengan tuntutan lingkungannya. Bentuk hubungan yang demikian dibuktikan dengan pengujian terhadap empat komponen atau variabel dasar yaitu tingkat formalitas dari struktur, orientasi tujuan organisasi, orientasi waktu, dan orientasi hubungan interpersonal.

\section{Sistem Informasi Akuntansi Manajemen}

Sistem informasi akuntansi manajemen (management accounting information system) adalah sistem informasi yang menghasilkan keluaran (output) dengan menggunakan masukan (input) dan memprosesnya untuk mencapai tujuan khusus manajemen (Soobaroyen, 2008). Sistem informasi akuntansi menurut Widjajanto (2001) adalah susunan formulir, catatan, peralatan termasuk komputer dan perlengkapannya serta alat komunikasi, tenaga pelaksanaannya dan laporan yang terkoordinasi secara erat yang didesain untuk mentransformasikan data keuangan menjadi informasi yang dibutuhkan manajemen. 
Chenhall dan Morris (1989) mengungkapkan ada beberapa karakteristik sistem infromasi akuntansi manajemen diantaranya Broad Scope (Lingkungan), Timelines (ketepatan waktu), Aggregation (agregasi), dan Integration (integrasi).

\section{Broad Scope}

Chenhall dan Morris (1986) mengatakan bahwa broad scope merupakan sistem infromasi yang mengaku pada dimensi fokus, kuantifikasi dan time horizon. Karakteristik sistem informasi akuntansi manajemen yang bersifat luas. Pada dasarnya menejemen memerulukan informasi dalam cangkupan yang luas oleh sebab itu dalam suatu manajemen perusahaan manajer memerlukan informasi yang memiliki broad scope. Broad scope dalam SIAM memberikan informasi yang terkait dengan lingkungan eksternal yang meliputi ekonomi seperti GNP, total penjualan pasar, dan bagian perusahaan dari pasar itu atau non ekonomi seperti faktor demografis dan kemajutan teknologi (Spencer et al, 2013).

\section{Timelines}

Ghesemi (2016) mengatakan bahwa kemampuan seorang manajer untuk merespons dengan cepat peristiwa yang mungkin juga dipengaruhi oleh timeliness dalam SIAM. Timelines biasanya ditentukan dalam hal penyedia informasi berdasarkan permintaan dan frekuensi pelaporan infromasi yang dikumpulkan secara sistematis. Timelines meningkatkan fasilitas SIAM untuk melaporkan peristiwa peristiwa terbaru dan untuk memberikan umpan balik yang cepat atas keputusan.

Agbejule (2005) menjelaskan karakteristik sistem informasi akuntansi manajemen mengenai ketetapan waktu dalam memperoleh informasi. Infromasi yang tepat mampu mempengaruhi kemampuan manajer dalam merespon suatu peristiwa atau permasalahan. Informasi yang tepat mampu mendukung manajer manghadapi ketidakpastian lingkungan yang terjadi dalam organisasi. Ghasemi (2016) dan Spencer et al (2013) mengungkapkan karakteristiks timelines mencangkup frekuensi pelaporan dan kecepatan membuat laporan.

\section{Aggregation / Agregrasi}

Menurut Spencer et al (2013) infromasi agregasi adalah gabungan dari penjumlahan temporal dan fungsional seperti area penjualan, pusat biaya, departemen pemasaran dan produksi, dan informasi yang dihasilkan khusus untuk model keputusan formal. Ghesemi (2016) menyatakan bahwa manajer yang terdesentralisasi cenderung lebih suka dievaluasi berdasarkan ukuran kinerja yang diagregasi dengan cara yang mencerminkan wilayah tanggung jawab mereka.

Karakteristik sistem infromasi akuntansi manajemen yang disajikan dalam bentuk yang lebih ringkas dan hanya mencangkup hal hal yang penting saja sehingga tidak mengurangi nilai infromasi itu sendiri. Karakteristik agregasi mencangkup fungsi, periode waktu dan model keputusan.Agregasi adalah proses dalam perencanaan keuangan perusahaan di mana proposal-proposal investasi kecil dari masingmasing unit operasional perusahaan digabungkan sehingga mendapatkan sebuah gambaran besar (Spencer et al, 2013).

\section{Integration / Integrasi}

Menurut Ghesemi (2016) infromasi yang mencerminkan kompleksitas dan saling keterkaitan antara bagian satu dan bagian lain. Infromasi yang terintegrasi mencerminkan adanya koordinasi antara segmen submit satu dan lainnya dalam organisasi. Infromasi yang terintegrasi berperan sebagai koordinator dalam mengendalikan pengambilan keputusan yang beraneka ragam. Timelines berarti dalam memperoleh infromasi suatu kejadian dibutuhkan ketetapan waktu yang baik. Infromasi dapat dikatakan tepat waktu apabila infromasi tersebut mencerminkan kondisi terkini dan sesuai dengan kebutuhan manajer.

Sistem infromasi akuntansi manajemen dengan adanya koordinasi antar segmen. Manfaat infromasi terintegrasi dirasakan penting pada saat manajer dihadapkan dengan situasi dimana harus mengambil 
keputusan yang mampu berdampak pada bagian atau unit lain. Semakin banyak jumlah segmen dan unit bisnis dalam organisasi akan semakin besar kebutuhn informasi terintegrasi memberikan peran perkoordinasian dalam beragam keputusan pada organisasi yang sangat terdesentralisasi (Spencer et al, 2013).

\section{Kinerja Manajerial}

Manajemen kinerja adalah suatu saranan untuk mendapatkan hasil lebih baik dari organisasi, tim dan individual dalam kerangka kerja yang disepakati dalam perencanaan tujuan, sasaran dan standar (Wibowo, 2016). Proses manajemen kinerja adalah proses dengan mana perusahaan mengelola kinerja selasar dengan strategi dan sasaran korporasi dan fungsional. Sasaran dari proses ini adalah mengusahakan sistem putaran tertutup secara proaktif, dimana strategi korporasi dan fungsional disebarkan pada semua proses aktivitas, tugas dan personil bisnis dan umpan balik diperoleh melalui sstem pengukuran kinerja untuk memungkinkan keputusan manajemen yang teapt ( Wibowo 2016).

Pengukuran terhadap kinerja perlu dilakukan untuk mengetahui apakah selama pelaksanaan kinerja terdapat deviasi dari rencana yang telah ditentukan, apakah kinerja dapat dilakukan sesuai jadwal waktu yang ditentukan, atau apakah hasil kinerja telah tercapai sesuai dengan yang dilakukan . Untuk melakukan pengukuran tersebut, diperlukan kemampuan untuk mengukur kinerja sehingga diperlukannya ukuran kinerja. Pengukuran kinerja hanya dapat dilakukan terhadap kinerja yang nyata dan terukur. Apabila kinerja tidak dapat terukur, tidak dapat dikelola. Untuk dapat memperbaiki kinerja, perlu diketahui seperti apa kinerja saat ini. Apabila deviasi kinerja dapat diukur dan diperbaiki (Wibowo, 2016).

Pengukuran kinerja yang tepat dapat dilakukan dengan cara : Memastikan bahwa persyaratan yang diinginkan pelanggan telah terpenuhi, mengusahakan standar kinerja untuk menciptakan perbandiangan, mengusahakan jarak bagi orang untuk memonitor tingkat kinerja, menetapkan arti penting masalah kualitas dan menentukan apa yang perlu prioritas perhatikan, Menghindari konsekuensi dari rendahnya kualitas, mempertimbangkan penggunaan sumber daya, mengusahakan umpan balik untuk mendorong usaha perbaikan.

Oleh karena itu, orang yang melakukan pengukuran kinerja perlu memenuhi persyaratan diantaranya (Kreitner dan Kinicki, 2001). Menurut Williams (2007) penilaian kinerja tidak lebih dari merupakan sebuah kartu laporan yang diberikan oleh atasan kepada bawahan, sautu keputusan tentang kecukupan atau kekurangan professional. Hal ini pada umumnya menunjukan apa kekurangan bawahan. Penilaian kinerja adalah proses dengan mana kinerja individual diukur dan dievaluasi. Penilaian kinerja menjawab pertanyaan, seberapa baik pekerja berkinerja selama periode waktu tertentu (Bacal, 2012).

\section{Kerangka Penelitian dan Pengembangan Hipotesis}

\section{Gambar 1 Kerangka Penelitian}

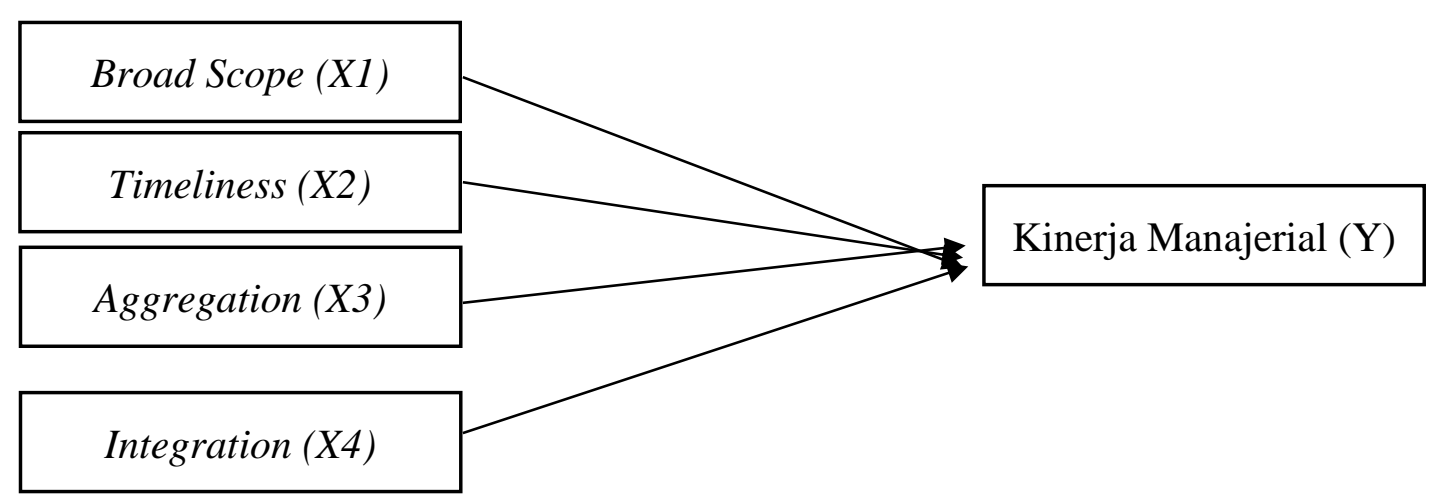




\section{Pengaruh Sistem Informasi Akuntansi Manajemen Broad Scope Terhadap Kineja Manajerial}

Spencer et al (2013) menyatakan bahwa sistem informasi akuntansi manajemen broad scope dianggap bermanfaat bagi manajer sub - unit desentralisasi, oleh sub - unit operasi dengan tingkat saling ketergantungan organisasi yang tinggi, dan menganggap situasi operasi mereka tidak pasti. Hasil penelitiannya menunjukan bahwa informasi broad scope secara luas signifikan terkait dengan ketidakpastian lingkungan yang dirasakan dan saling ketergantungan organisasi. Soobaroyen (2008) menyatakan bahwa pentingnya infromasi berorientasi masa depan kepada manajer yang menghadapi ketidakpastian. Hasil penelitiannyabroad scope akan membantu kontrol dalam situasi yang tidak pasti dengan menfokuskan infromasi pada ketidakpastian sumber. Sulasni dan Dani (2013) dalam penelitiannya menunjukan hasil bahwa broad scope memiliki dampak yang baik dan signifikan untuk peningkatan kinerja manajerial. Berdasarkan beberapa hasil penelitian sebelumnya maka dapat dirumuskan hipotesisnya sebagai berikut :

\section{H1 : Broad scope berpengaruh positifterhadap Kinerja Manajerial.}

\section{Pengaruh Sistem Informasi Akuntansi Manajemen Timelines Terhadap Kinerja Manajerial}

Menurut Spencer et al (2013) sistem informasi akuntansi manajemen timelines mempengaruhi kemampuan para manajer untuk dengan tanggap merespon secara tepat atas suatu peristiwa. Timelines sendiri mencangkup kecepatan pelaporan dan frekuensi pelaporan. Hasil penelitiannya menyatakan bahwa sistem infromasi akuntnasi timeliness mempengaruhi kinerja manajerial secara signifikan. Peneliti Agbejule (2011) dalam penelitiannya menyatakan bahwa timing informasi menunjuk kepada jarak waktu antara permintaan dan tersedianya informasi dari SIAM ke pihak yang meminta. Semakin cepat jarak waktu yang tersedia, semakin cepat seorang manajer mengambil keputusan infromasi yang tepat waktu yang mampu memberikan umpan balik yang cepat terhadap sebuah keputusan, adanya umpan balik yang cepat mengakibatkan meningkatnya kinerja manajerial. Sulasni dan Dendi (2013) dalam penelitiannya menyatakan sistem infromasi akuntansi manajemen timelinessmenunjukan hasil yang sangat baik dan berdampak positif signifikan terhadap kineja manajerial. Berdasarkan beberapa hasil penelitian sebelumnya maka dapat dirumuskan hipotesisnya sebagai berikut :

\section{H2 : Timeliness berpengaruh positifterhadap Kinerja Manajerial.}

\section{Pengaruh Sistem Informasi Akuntansi Manajemen Aggregation Terhadap Kinerja Manajerial}

Menurut Chenhall dan Morris (1986) sistem infromasi akuntasni manajemen agregasi mulai dari penyediaan data mentah, tidak diproses hingga beragam agregasi di sekitar periode waktu bidang yang diminati seperti pusat pertanggungjawaban, atau area fungsional. Tipe tambahan agregasi mengacu pada penjumlahan dalam format yang konsisten dengan model keputusan formal seperti diskon analisis arus kas untuk penganggaran modal, simulasi dan pemograman linie dalam aplikasi budgetary, analisis laba dan volume biaya. Hasil penelitiannya menyatakan bahawa informasi agregasi mempengaruhi pertanggungjawaban kinerja manajerial. Spencer et al (2013) menyatakan bahwa informasi yang teragregasi dengan tepat akan memberikan masukan yang penting dalam proses pengambilan keputusan, karena waktu yang dibutuhkan untuk mengevaluasi infromasi menjadi lebih sedikit daripada informasi yang tidak teragregasi. pada saat ketidakpastian lingkungan meningkat manajer akan membuthkan informasi dengan karakteristik informasi yang berorientasi agregasi agar keputusan yang diambil dapat efektif. Sulasni dan Dandi (2013) menyatakan dalam penelitiannya bahwa agregasi menunjukan nilai yang sangat baik dalam pengambilan keputusan dari suaatu informasi yang teragregasi untuk meningkatkan kinerja manajerial. Berdasarkan beberapa hasil penelitian sebelumnya maka dapat dirumuskan hipotesisnya sebagai berikut :

H3 : Aggregation berpengaruh positifterhadap Kinerja Manajerial. 


\section{Pengaruh Sistem Informasi Akuntansi Manajemen Integration Terhadap Kinerja Manajerial}

Informasi yang terintegrasi memiliki peran sebagai koordinator dalam mengendalikan pengambilan keputusan. Chia (1995) juga menyatakan informasi yang terintegrasi dalam SIAM dapat digunakan sebagai alat koordinasi antar segmen dari sub unit dan antar subunit. Kompleksifitas tersebut termasuk juga dalam hal ketahanan menghadapi situasi ketidakpastian lingkungan, semakin baik informasi yang terntegrasi maka semakin baik pula manajemen dalam menghadapi situasi ketidakpastian lingkungan. Aspek pengendalian suatu organisasi yang penting adalah koordinasi berbagai segmen dalam sub organisasi. Karakteristik sistem akuntansi manajemen yang membantu koordinasi mencakup spesifikasi target yang menunjukkan pengaruh interaksi segmen dan informasi mengenai pengaruh keputusan pada operasi seluruh sub-sub unit organisasi (Agbejule, 2011). Sulasni dan Dendi (2013) menyatakan dalam penelitiannya bahwa informasi teritegrasi dalam suatu manajemen perusahaan menunjukan hasil yang sangat baik dalam meningkatakn kinerja manajerial.Berdasarkan beberapa hasil penelitian sebelumnya maka dapat dirumuskan hipotesisnya sebagai berikut :

\section{H4 : Integration berpengaruh positifterhadap Kinerja Manajerial.}

\section{METODE PENELITIAN}

Data yang digunakan penelitian ini didapatkan dengan menyebar kuisioner secara langsung ke Bank Pengkreditan Rakyat yang ada di Bandar Lampung. Adapun jumlah populasi dari penelitian ini adalah sebanyak 100 manajer atau setara manajer dimana penulis memilih untuk menggunakan seluruh populasi tersebut untuk menjadi bagian dari sample penelitian ini.

Tabel 1 Perhitungan Populasi Manajer dan Setara Manajer

\begin{tabular}{llc}
\hline No & \multicolumn{1}{c}{ Nama Bank } & Populasi \\
\hline 1. & BPR Waway Kota Bandar Lampung & 25 \\
2. & BPR Arta Kedaton Makmur & 10 \\
3. & BPR Dana Selaras Sentosa & 10 \\
$\mathbf{4 .}$ & PT BPR Inti Dana Sentosa & 10 \\
$\mathbf{5 .}$ & PT BPR Langgeng & 25 \\
$\mathbf{6 .}$ & BPR EKA BUMI ARTHA & 20 \\
\hline & Jumlah
\end{tabular}

Sumber : Data kuisioner yang terlah diolah, 2020

\section{Karakteristik Responden}

Responden dalam penelitian ini dibagi berdasarkan jenis kelamin, usia, lama bekerja dan pendidikan terakhir. Adapun sampel responden sebagai berikut:

Tabel 2 Data Statistik Responden Berdasarkan Jenis Kelamin

\begin{tabular}{lcc}
\hline Jenis kelamin & Jumlah & Persentase \\
\hline Laki laki & 72 & $72 \%$ \\
Perempuan & 28 & $28 \%$ \\
\hline Total & $\mathbf{1 0 0}$ & $\mathbf{1 0 0 \%}$
\end{tabular}

Sumber : Data Kuisioner yang telah diolah, 2020

Dari data kuisioner yang telah dilakukan oleh peneliti dan telah diolah, diketahui bahwa jumlah responden laki - laki sebanyak 72 responden atau $72 \%$ dan jumlah responden perempuan sebanyak 28 responden atau $28 \%$. 
Tabel 3 Usia Responden

\begin{tabular}{ccc}
\hline Usia & Jumlah & Persentase \\
\hline $\mathbf{2 5}-\mathbf{3 5}$ tahun & 30 & $30 \%$ \\
$\mathbf{3 6}-\mathbf{4 5}$ tahun & 55 & $55 \%$ \\
$\mathbf{4 6}-\mathbf{5 5}$ tahun & 15 & $15 \%$ \\
\hline Total & $\mathbf{1 0 0}$ & $\mathbf{1 0 0 \%}$
\end{tabular}

Sumber : Data Kuisioner yang telah diolah, 2020

Berdasarkan tabel 3 bahwa karakteristik usia responden yang berusia 25 - 35 tahun adalah 30 orang atau 30\%. Responden dengan usia 36 - 45 tahun adalah 55 orang atau 55\% dan responden dengan usia 46 -55 tahun adalah 15 orang atau $25 \%$.

Tabel 4 Pendidikan Terakhir

\begin{tabular}{ccc}
\hline Pendidikan Terakhir & Jumlah & Presentase \\
\hline SMA/SLTA & 5 & $5 \%$ \\
DIPLOMA & 30 & $30 \%$ \\
SARJANA & 65 & $65 \%$ \\
\hline Total & $\mathbf{1 0 0}$ & $\mathbf{1 0 0} \%$
\end{tabular}

Sumber : Data kuisioner yang telah diolah, 2020

Berdasarkan tabel 4 bahwa karakteristik responden pendidikan terakhir SMA/SLTA adalah 5 responden atau 5\%, responden diploma sebanyak 30 responden atau 30\%, dan responden sarjana sebanyak 65 responden atau $65 \%$.

\section{ANALISIS DAN PEMBAHASAN}

\section{Koefisien Determinasi}

Koefisien determinasi mengukur sejauh mana variabel - variabel independen yang ada dalam model menerangkan keterikaatannya dengan variabel dependen. koefisien determinasi ini digunakan untuk mengukur seberapa jauh variabel-variabel bebas dalam menerangkan variabel terikatnya. Penelitian ini menggunakan 4 variabel independen sehingga menggunakan Adjusted R untuk melihat hubungan antara dua variabel yaitu variabel dependen dan independen. Berikut hasil perhitungan dan output dari koefisien (Adjusted R):

Tabel 5 Hasil Perhitungan Kofisien Determinasi Model Summary

\begin{tabular}{|l|r|r|r|r|}
\hline Model & $\mathrm{R}$ & $\mathrm{R}$ Square & $\begin{array}{c}\text { Adjusted R } \\
\text { Square }\end{array}$ & $\begin{array}{c}\text { Std. Error of } \\
\text { the Estimate }\end{array}$ \\
\hline 1 & $.987 \mathrm{a}$ &, 974 &, 973 &, 58245 \\
\hline
\end{tabular}

a. Predictors: (Constant), X4, X2, X1, X3

b. Dependent Variable: Y

Sumber : SPSS versi 20 for Windows

Berdasarkan hasil tabel 5 dapat diketahui nilai Adjusted R sebesar 0,973 yang berarti variabilitas variabel kinerja manajerial pada BPR di Kota Bandar Lampung dapat dijelaskan oleh variabelbroad scope, timelines, aggregation, dan integration sebesar 97\% dan sisanya 3\% dijelaskan oleh variabel lainnya. 


\section{Uji Statistik F}

Pengujian ini digunakan untuk menunjukan apakah keseluruhan variabel independen secara bersama sama dapat berpengaruh terhadap variabel dependennya. Pengujian ini dilakukan dengan uji $\mathrm{F}$ pada tingkat kepercayaan $95 \%$ atau sig sebesar 0,05 . Berikut adalah hasil pengujian uji statistik $\mathrm{F}$ dalam penelitian ini:

\section{Tabel 6 Hasil Perhitungan Uji Statistik F}

\begin{tabular}{|l|r|r|r|r|r|}
\hline \multicolumn{1}{|c|}{ ANOVA $^{\mathrm{a}}$} \\
\multicolumn{1}{|c|}{$\begin{array}{c}\text { Sum of } \\
\text { Squares }\end{array}$} & df & $\begin{array}{c}\text { Mean } \\
\text { Square }\end{array}$ & F & Sig. \\
\hline 1 Regression & 1210,331 & 4 & 302,583 & 891,916 & $.000^{\mathrm{b}}$ \\
& & & & & \\
Residual & 32,229 & 95 &, 339 & & \\
Total & 1242,560 & 99 & & & \\
\hline
\end{tabular}

a. Dependent Variable: $Y$

b. Predictors: (Constant), X4, X2, X1, X3

Sumber : SPSS versi 20 for Windows

Berdasarkan hasil pada tabel di atas dapat dilihat bahwa F hitung $=891,916>$ Ftabel $=2,47$ dengan nilai siginifikan sebesar $0,000<0,05$ yang berartibroadscope, timelines, aggregation dan integration mempunyai pengaruh secara signifikan terhadap kinerja manajerial di BPR Kota Bandar Lampung. Berdasarkan hasil di atas berarti broadscope, timelines, aggregation dan integration secara bersama-sama mempunyai pengaruh yang positif dan signifikan terhadap kinerja manajarial di BPR Kota Bandar Lampung.

\section{Uji Statistik T}

Pengujian ini bertujuan untuk mengetahui ada atau tidaknya pengaruh terpisah dari masing-masing variabel bebas terhadap variabel terikat dengan menggunakan uji t pada tingkat kepercayaan 95\% $(\alpha=$ $0,05 \%)$.

Tabel 6 Hasil Uji T

Coefficients ${ }^{\mathbf{a}}$

\begin{tabular}{|c|c|c|c|c|c|}
\hline \multirow[b]{2}{*}{ Model } & \multicolumn{2}{|c|}{ Unstandardized Coefficients } & \multirow{2}{*}{$\begin{array}{c}\text { Standardized } \\
\text { Coefficients } \\
\text { Beta } \\
\end{array}$} & \multirow[b]{2}{*}{$\mathrm{T}$} & \multirow[b]{2}{*}{ Sig. } \\
\hline & $\mathrm{B}$ & Std. Error & & & \\
\hline $1 \quad$ (Constant) & 3,489 & ,722 & & 4,833 &, 000 \\
\hline $\mathrm{X} 1$ & ,264 & ,064 & ,208 & 4,126 & ,000 \\
\hline $\mathrm{X} 2$ & ,523 & ,083 & ,292 & 6,315 & ,000 \\
\hline X3 & ,316 & 075 & 248 & 4,205 & ,000 \\
\hline $\mathrm{X} 4$ & ,597 & ,086 & ,279 & 6,962 & 000 \\
\hline
\end{tabular}

a. Dependent Variable: Y

Berdasarkan hasil perhitungan tersebut maka diperoleh persamaan regresi sebagai berikut:

$$
Y=3.489+0,264 X 1+0,523 X 2+0,316 X 3+0,597 X 4+e
$$

Keterangan: $\mathrm{Y}=$ Kinerja Manajerial

$\mathrm{X} 1=$ Broadscope

$$
\mathrm{e}=\text { error }
$$

$\mathrm{X} 2=$ Timelines

$\mathrm{X} 3$ = Aggregation

$\mathrm{X} 4$ = Integration 
Berdasarkan hasil uji statistik dan persamaan regresi di atas maka dapat dijelaskan sebagai berikut:

1. Nilai konstanta adalah nilai yang bersifat tidak bisa diubah atau ditetapkan.

Nilai konstanta sebesar 3.489 artinya jika variabel broadscope, timelines, aggregation dan integration nilainya adalah 0 maka kinerja manajerial (Y) nilainya akan tetap 3.489. Nilai konstanta tidak mempengaruhi variabel lainnya.

2. Berdasarkan tabel diatas tingkat signifikansi variabel broad scope

(X1) adalah sebesar 0,00 (nilai signifikansi > 0,05). Hal tersebutmenunjukkan broadscope berpengaruh signifikan terhadap Kinerja Manajerial.

Berdasarkan persamaan regresi diketahui bahwa nilai koefisien variabel

Broad scope (X1) yaitu sebesar 0,264 bernilai positif, sehingga hal ini membuktikan bahwa Broad scope berpengaruh signifikan terhadap kinerja manajerial. Dengan demikian hipotesis yang menyatakan "Broad scope berpengaruh positif terhadap Kinerja Manajerial" Terdukung.

3. Berdasarkan tabel diatas tingkat signifikansi variabel timelines (X2) sebesar 0,000 (nilai signifikansi $<0,05)$. Hal tersebut menunjukkan bahwa variabel timelines berpengaruh signifikan terhadap Kinerja Manajerial (Y). Berdasarkan persamaan regresi diketahui bahwa nilai koefisien variabel timelines (X2) yaitu sebesar 0,523 bernilai positif, sehingga hal ini membuktikan bahwa timelines berpengaruh positif terhadap kinerja manajerial. Dengan demikian hipotesis yang menyatakan "Timelines berpengaruh positif terhadap kinerja manajerial." Terdukung.

4. Berdasarkan tabel diatas tingkat signifikansi variabel aggregation (X3) sebesar 0,000 (nilai signifikansi < 0,05). Hal tersebut menunjukkan bahwa variabel aggregation berpengaruh signifikan terhadap Kinerja Manajerial (Y). Berdasarkan persamaan regresi diketahui bahwa nilai koefisien variabel timelines(X3) yaitu sebesar 0,316 bernilai positif, sehingga hal ini membuktikan bahwa aggregation berpengaruh positif terhadap kinerja manajerial. Dengan demikian hipotesis yang menyatakan "Aggregation berpengaruh positif terhadap kinerja manajerial." Terdukung.

5. Berdasarkan tabel diatas tingkat signifikansi variabel integration (X4) sebesar 0,000 (nilai signifikansi < 0,05). Hal tersebut menunjukkan bahwa variabel timelines berpengaruh signifikan terhadap Kinerja Manajerial (Y). Berdasarkan persamaan regresi diketahui bahwa nilai koefisien variabel integration (X4) yaitu sebesar 0,597 bernilai positif, sehingga hal ini membuktikan bahwa integration berpengaruh positif terhadap kinerja manajerial. Dengan demikian hipotesis yang menyatakan "Integration berpengaruh positif terhadap kinerja manajerial." Terdukung.

\section{E. SIMPULAN DAN SARAN}

Penelitian ini bertujuan untuk mengetahui adanya pengaruh sistem informasi akuntansi manajemen terhadap kinerja manajerial di BPR Kota Bandar Lampung. Responden yang berhasil didapat dalam penelitian ini berjumlah 100 responden. Berdasarkan hasil analisis dalam penelitian ini didapatkan beberapa kesimpulan sebagai berikut :

1. Broadscope berpengaruh terhadap kinerja manajerial di BPR Kota Bandar Lampung, tujuan sistem infromasi akuntansi manajemen broadscope membantu manajer dalam mengolah infromasi dari luar maupun eksternal perusahaan. Semakin luas cangkupan infromasi yang diperoleh dalam suatu perusahaan maka akan meningkatkan kinerja manajerial terutama dalam hal pengambilan keputusan.

2. Timelines berpengaruh terhadap kinerja manajerial di BPR Kota Bandar Lampung, dalam ketepatan dan kecepetan pelaporan di BPR Kota Bandar Lampung berlangsung dengan baik dan tepat waktu 
sesuai dengan permintaan informasi ketika diminta oleh manajer. Hal ini berguna untuk pengambilan keputusan untuk meningkatkan kinerja manajerial di BPR Kota Bandar Lampung.

3. Aggregation berpengaruh terhadap kinerja manajerial di BPR Kota Bandar Lampung, apabila informasi bersifat teragregasi dapat memberikan model keputusan yang tepat dengan waktu yang diperlukan untuk mengevaluasi informasi yang lebih efektif dan relatif pendek dibandingkan dengan infromasi yang bersifat parsial. Hal ini berguna untuk menyampaikan infromasi dengan lebih ringkas dan mencangkup hal - hal penting tanpa mengurangi nilai informasi itu sendiri, ringkasnya infromasi juga mningkatkan efisiensi kerja manajemen. Infomasi yang teragregasi memungkinkan untuk membuat model keputusan seperti analisis kas, aliran biaya dan analisis kebijakan perusahaan, adanya informasi yang lebih ringkas menunjukan baiknya kinerja manajerial dan meningkatkan kinerja manajerial di BPR Kota Bandar Lampung.

4. Integration berpengaruh terhadap kinerja manajerial di BPR Kota Bandar Lampung, informasi yang disediakan pada bagian sub unit lain dengan fungsional yang berbeda seperti pusat laba, marketing, account officer, bag. Akuntansi dan pusat pembiayaan informasi ini mencerminkan adanya kompleksitas dan saling keterkaitan antara sub bagian lain dengan sub lainnya. Dampak dari terintegrasi suatu infromasi akan dirasakan oleh manajer persub bagian untuk pengambilan keputusan guna meningkatkan kinerja manajerial di BPR Kota Bandar Lampung.

\section{Saran}

1. Diharapkan penelitian ini dapat memberikan maanfaat dalam pengembangan praktek akuntansi dan sistem informasi akuntansi manajemen pada perusahaan BPR di Bandar Lampung khususnya dalam penyedia infromasi dan pengguna infromasi itu sendiri, bagaimanapun karakteristik informasi itu sendiri akan bermanfaat jika digunaakan oleh pengguna informasi yang tepat.

2. Bagi peneliti selanjutnya disarankan untuk sebisa mungkin menambah sampel responden, karena semakin banyak jumlah sampel yang digunakan semakin baik pula hasil penelitiannya.

\section{REFERENSI}

Agbejule, Adebayo. 2011. Organizational culture and performance: the role of management accounting system.Journal of Applied Accounting Research, Vol. 12 Issue: 1, pp.74-89.

Agbejue, Adebayo. 2005. The relationship between management accounting systems and perceived environmental uncertainty on managerial performance: a research note.Journal of Applied Accounting Research, Vol. 35 No. 4, pp. 295-305.

Chenhall dan Moris. 1986. The impact ofenvironment and interdependence on The perceived usefulness of management accounting systems. Accounting Review.

Chia. 1995. Decentralication, Management Accounting System (MAS) Information Characteristic and their interaction effect on Managerial Performance: A .Singapore Study. Journal Accounting Review.

Ghasemi, Reza et al (2016) The mediating effect of management accounting system on the relationship between competition and managerial performance.International Journal of Accounting and Information Management, Vol. 24 Issue: 3, pp.272-295.

Ghozali, I. 2013. Aplikasi analisis Multivariate dengan program IBM SPSS 20. Semarang: Universitas Diponegoro. Lubis, Arfan Ikhsan. 2010. Akuntansi Keprilakuan. Edisi ke-2. Jakarta: Salemba Empat.

Mahoney et al. 1965. The Job(s) of Management. Industrial realations , Pp 97-110

Sigilipu, Steffi. 2013. Pengaruh Penerapan Informasi Akuntansi Manajemen dan Sistem pengukuran kinerja Terhadap Kinerja Manajerial. Jurnal EMBA. Vol. 1 No. 3.

Soobaroyen, Teerooven. 2008. The effectiveness of management accounting system Evidence from Functional managers in a developing country. Accounting Review.

Spencer, Sarah Yang, et al. 2013. The Mediating Effect of The Adoption of An Environmental Information System on Top Management's Commitment and Environmental Performance. Sustainability Accounting, Management and Policy Journal, Vol. 4 Issue; 1, pp. 75-102.

Sugiyono. 2010. Metode Penelitian Pendidikan (Pendekatan Kuantitatif, Kualitatif, dan R\&D).Bandung: CV Alfabeta. 
Sulasni, Sri dan Dendi. 2013. Pengaruh karakteristik sistem informasi akuntansi menejemen terhadap kinerja manajerial (Studi Kasus BPR Kabupaten Demak). Jurnal Akuntansi dan Keuangan. Vol 3 No. 2.

Wibowo. 2016. Manajemen Kinerja. Edisi ke-5. Jakarta: PT. RajaGrafindo Persada.

William, Monci J. 2007. Managing Performance to Maximise Result, Performance Appraisals is Dead. Long Live Performance Management. Boston: Harvard Business School Publishing Corporation. 